\title{
Pleural drainage and pleurodesis: implementation of guidelines in four hospitals
}

\author{
J.A. Burgers*, P.W.A. Kunst ${ }^{\#}$, M.G.J. Koolen ${ }^{\star}$, L.N.A. Willems ${ }^{+}$, \\ J.S. Burgers ${ }^{\S}$ and $M$. van den Heuvel*
}

ABSTRACT: The aim of the present study was to evaluate the implementation of the 2003 Dutch guideline on the diagnosis and treatment of malignant pleural effusions, and the potential effect of the implementation on the clinical outcome of pleurodesis.

All patients with malignant pleural effusion who had a pleural drain placed with the intention of performing pleurodesis were registered prospectively in four centres. Details of the procedure and fluid recurrence and survival data were noted.

Patients with a proven malignancy $(n=100)$ were entered into the registration database. Diagnostic guideline recommendations were followed in $60-70 \%$ of the patients. Surprisingly, pleurodesis was performed in only $75 \%$ of the patients, mainly due to the presence of a trapped lung. All pleurodeses were performed using talc, according to the guideline. Follow-up revealed fluid recurrence in 27 (36\%) patients after a mean follow-up of 17 days (range 2-285 days); 14 patients with successful pleurodesis died with a median survival of 61 days (range 13-174 days). Systemic treatment following pleurodesis and good apposition of the pleural surfaces during drainage were good prognostic factors.

Despite reasonable-to-good adherence to the guideline, the number of successful pleurodeses was low. Better predictors of a good pleurodesis outcome are needed.

KEYWORDS: Guidelines, malignant pleurisy, pleurodesis, predictive factors, talc

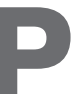
leural effusions occur in $\sim 50 \%$ of patients with metastatic malignancies [1]. The majority of the pleural effusions occur due to metastatic spread of the tumour to the pleural surface. This is generally accompanied by symptoms of dyspnoea and cough, which can severely affect quality of life (QoL). Malignant pleural effusions are most frequently encountered in breast cancer and nonsmall cell lung cancer, but can occur in any malignancy. Pleural metastases are most often seen in end-stage disease and optimal palliation is mandatory.

In order to optimise the treatment of malignant pleural effusions in the Netherlands, a clinical practice guideline was developed under supervision of the Dutch Society of Pulmonologists (NVALT) and distributed to all chest physicians [2]. The guidelines consist of diagnostic and therapeutic recommendations, including levels of evidence according to the Dutch Institute for Healthcare Improvement $\mathrm{CBO}$ (Utrecht, the Netherlands) grading system [3, 4]. As expected, great overlap occurs between different guidelines, although the same data result in recommendations with varying grades of evidence (table 1). The Dutch guideline corresponds piratory Society (ERS) and the American Thoracic Society (ATS), who, however, did not use a grading system for their recommendations [7]. The British Thoracic Society (BTS) guideline covers a wide range of additional issues [8,9], and the most recent guideline from Spain (2005) supports previous proposals [10].

Patients in four Dutch hospitals (Netherlands Cancer Institute, Medical Centre of the Free University and Academic Medical Centre, University of Amsterdam (all Amsterdam) and Leiden University Medical Centre (Leiden)) with (suspected) malignant pleural effusion $(n=100)$ were registered prospectively in order to measure adherence to the guideline, and its impact on patient outcome. Furthermore, the methods detailed in recent literature were summarised in order to select patients for studies on pleurodesis and calculate the success rates of pleurodesis. with the joint statement of the European Res-
AFFILIATIONS

*Netherlands Cancer Institute, ${ }^{\text {\#} M e d i c a l ~ C e n t r e ~ o f ~ t h e ~ F r e e ~}$ University,

"Academic Medical Centre University of Amsterdam, Amsterdam,

+Leiden University Medical Centre, Leiden, and

${ }^{\S}$ Dutch Institute for Healthcare Improvement CBO, Utrecht, the Netherlands.

CORRESPONDENCE

J.A. Burgers

Dept of Thoracic Oncology Netherlands Cancer Institute

Plesmanlaan 121

1066 CX Amsterdam

The Netherlands

Fax: 31205122572

E-mail: s.burgers@nki.nl

Received:

December 072007

Accepted after revision:

June 222008

STATEMENT OF INTEREST

A statement of interest for J.A. Burgers can be found at

www.erj.ersjournals.com/misc/ statements.shtml 


\section{PATIENTS AND METHODS}

The present study was designed to monitor the daily practice of pleural drainage and pleurodesis. Two inclusion criteria were established. The patients had to have a proven malignancy (any malignancy was eligible) and a pleural drain had to be placed with the intention of performing pleurodesis. All patients were registered anonymously in a central database.

No written or verbal instructions were given to the participating centres concerning patient selection, diagnostic procedures or the intervention as such. The participating pulmonologists stated that they had received and were aware of the guideline, and intended to apply the guideline in clinical practice.

Of the four hospitals, three (Medical Centre of the Free University, Academic Medical Centre and Leiden University Medical Centre) were teaching clinics with registrars and consultants performing the interventions; the other (Netherlands Cancer Institute) was a national oncological referral centre.

The medical ethics committee of the Netherlands Cancer Institute decided that individual informed consent was not required since the study involved only anonymous registration of a standard treatment.

The registry was internet-based (currently accessible only by those involved in the study), and consisted of four pages concerning the diagnostic and therapeutic procedures that were performed before the drain was placed and details about the drain, pleurodesis and follow-up. Follow-up was not standardised but was left to the discretion of the respiratory physician. The minimum duration of follow-up was 70 days following pleurodesis.

\section{Statistics}

A procedure was considered successful when the patient was alive without fluid recurrence after 2 months. Univariate and multivariate logistic regression were performed in order to investigate the prognostic value for successful pleurodesis of the following factors: lactate dehydrogenase (LDH), glucose and total protein levels, obtention of cytological or histological confirmation of malignant pleural effusion, drain size and time, relief of complaints by preceding thoracentesis, expansion of the lung following drainage, and systemic antitumour treatment following pleurodesis. All analyses were performed with the significance level set at 0.05 .

\section{RESULTS}

During the period between February 1, 2006 and November 30, 2006, 100 consecutive patients were registered in the database. All of the patients exhibited a pathologically proven malignancy. Details are given in table 2 .

\section{Adherence to the guideline}

The diagnostic or therapeutic interventions performed before the drainage, the tests performed on pleural fluid samples taken either before or during the procedure, and the method by which a definite diagnosis of malignant pleurisy was obtained are given in table 3 . Other tests that were performed included albumin level in 21 patients and leukocyte count and haemoglobin, carcinoembryonic antigen, amylase and bilirubin levels, all in three or less patients.
All of the patients experienced uneventful drain insertion. Drain size ranged $15-24 \mathrm{Ch}$, with 66 drains of $20 \mathrm{Ch}$ in diameter. Of the patients, 75 underwent pleurodesis, all procedures being performed with talc (74 slurry and one talc poudrage) at a dose ranging $2-5 \mathrm{~g}$. The reasons for not performing pleurodesis were trapped lung $(n=15)$, persisting high fluid production $(n=3)$, rapid clinical deterioration $(n=3)$, technical drain problems $(n=2)$, no cytological confirmation of the diagnosis malignant pleurisy $(n=3)$, persisting chylothorax $(n=1)$ and empyema and subsequent thoracotomy $(n=1)$. In some patients, more than one reason was applicable for not performing the pleurodesis.

Complications of the procedure were pain $(n=11)$, fever following pleurodesis $(n=8)$, technical drain problems $(n=5)$, subcutaneous emphysema $(n=2)$ and local haematoma $(n=1)$. Late complications included tumour ingrowth in the scar $(n=1)$, empyema $(n=1)$ and severe restriction $(n=4)$.

\section{Outcome of the procedures}

During the procedure, chest radiography was performed in 95 patients, revealing residual fluid $(n=29)$, hydropneumothorax $(n=14)$, trapped lung $(n=8)$ or disappearance of the fluid and fully expanding lung $(n=43)$. Pleurodesis was performed a median of 3 days (range 0-15 days) after the start of drainage. The drain was removed after 5 days (2-21 days) in the case of pleurodesis and after 4 days ( $0-9$ days) when no pleurodesis was performed.

Following pleurodesis $(n=75)$, radiological imaging results were available for 64 patients. A recurrence of pleural fluid was seen in 27 (36\%) patients at 17 days (2-285 days) following pleurodesis; in 11 (15\%) patients, no radiological follow-up was performed; and 44 patients, 14 of whom died during follow-up, showed no fluid recurrence following pleurodesis. They exhibited a survival of 61 days (13-174 days). The proportion of successful drain and pleurodesis procedures by intention-to-treat analysis according to the criteria that were initially set to define successful pleurodesis was $25 \%$. Excluding patients from this analysis who did not undergo pleurodesis leads to a success proportion of $47 \%$ (35 out of 75 patients). Changing the definition of success to free of fluid recurrence for $\geqslant 70$ days and including those patients who died without documented fluid recurrence within this period of time raised the success proportion to $71 \%$ (53 out of 75 ).

Factors predictive of successful pleurodesis were systemic antitumour treatment given following pleurodesis $(\mathrm{p}=0.0001)$ and good apposition of the pleural surfaces during drainage $(p=0.03)$. LDH level, $\mathrm{pH}$, drain time, drain size, dose of talc, tumour type or hospital were not significantly correlated with the outcome of pleurodesis.

\section{DISCUSSION}

In 2003, the Dutch guideline on malignant pleural effusions, based on the best available evidence, was published and disseminated to all respiratory physicians in the Netherlands. Its use has been recommended by the NVALT.

Guidelines, however, do not implement themselves [11]. Healthcare professionals are often reluctant to change their behaviour or routine habits [12]. Multiple or tailored implementation strategies are required in order to effectively change 
TABLE 1 Summary of guidelines on malignant pleural effusion

\begin{tabular}{|c|c|c|c|c|c|c|}
\hline & \multicolumn{2}{|l|}{ NVALT\# } & \multirow[t]{2}{*}{ ERS/ATS } & \multirow[t]{2}{*}{ BTS $^{\S}$} & \multirow[t]{2}{*}{ SEPAR $^{f}$} & \multirow{2}{*}{$\begin{array}{l}\text { Adherence } \\
\text { monitored in } \\
\text { present study }\end{array}$} \\
\hline & Recommendation & $\begin{array}{l}\text { Level of } \\
\text { evidence }{ }^{\# \#}\end{array}$ & & & & \\
\hline \multirow[t]{3}{*}{ Diagnosis } & $\begin{array}{l}\text { Symptomatic pleural fluid collections can } \\
\text { be visualised by CXR }\end{array}$ & B & + & B & + & \\
\hline & $\begin{array}{c}\text { Thoracoscopy may be performed when } \\
\text { thoracentesis is not diagnostic }\end{array}$ & $\mathrm{D}$ & + & B & C & \\
\hline & $\begin{array}{l}\text { Abrams' biopsy is not recommended } \\
\text { to exclude a malignant } \\
\text { origin of pleural fluid }\end{array}$ & $\mathrm{D}$ & "is less sensitive" & $\begin{array}{l}\text { D; take } \geqslant 4 \\
\text { biopsy } \\
\text { specimens }\end{array}$ & $\begin{array}{l}\text { D; take } \geqslant 4 \\
\text { biopsy } \\
\text { specimens }\end{array}$ & \\
\hline \multirow{4}{*}{ Treatment } & Less successful pleurodeses at lower $\mathrm{pH}$ & + & 0 & 0 & D & \\
\hline & $\begin{array}{l}\text { Malignant pleural effusion in NSCLC } \\
\text { designates at least stage IIIB } \\
\text { tumour; when not symptomatic, } \\
\text { chemotherapy should be considered } \\
\text { if not otherwise contraindicated }\end{array}$ & A & + & 0 & 0 & \\
\hline & $\begin{array}{l}\text { Systemic therapy as well as pleurodesis } \\
\text { (or both) should be considered as } \\
\text { therapeutic options }\end{array}$ & B & + & 0 & + & Yes \\
\hline & $\begin{array}{c}\text { Talc pleurodesis, by either slurry or } \\
\text { nebulisation, shows the lowest } \\
\text { number of failures }\end{array}$ & A & + & B & B & Yes \\
\hline
\end{tabular}

Levels of evidence were as follows: A: appropriate data available, including at least one well-executed randomised controlled trial; B: data available from controlled trials with low statistical power, or from nonrandomised or cohort studies; C: data available from nonrandomised studies; D: appropriate data are not available, with the recommendation representing the opinion of the committee $[3,4]$. The British Thoracic Society (BTS) used a three-step grading system [5], which was transposed to the four-step grading system used by the other guidelines (BTS grade C becomes D). The Brazilian guideline [6] was not listed since no English version was available. NVALT: Dutch Society of Pulmonologists; ERS: European Respiratory Society; ATS: American Thoracic Society; BTS: British Thoracic Society; SEPAR: Spanish Society of Pulmonology And Thoracic Surgery; CXR: chest radiography; LDH: lactate dehydrogenase; NSCLC: nonsmall cell lung cancer; TCC: total cell count; DCC: differential cell count. +: mentioned without level of evidence; 0: not mentioned. ${ }^{\#:} 2003$ [2]; ${ }^{\prime}: 2001$ [7]; \$.: 2003 [8, 9]; ${ }^{f}: 2006$ [10]; \#\#: grade assigned by the committee for each recommendation.

provider behaviour. In the present study, adherence to the guideline, which was implemented without specific strategies, was measured.

The diagnostic recommendations of the guideline regarding malignant pleural effusion were not uniformly followed. Pathological confirmation of the malignant nature of the effusion was obtained in $63 \%$ of the patients. Recommended predictors of pleurodesis effectiveness, such as LDH and total protein level and $\mathrm{pH}$ were measured in 82,75 and $46 \%$ of patients, respectively. In the present series, these parameters did not correlate with the pleurodesis success rate, which is in line with some studies but in contrast with others [13, 14]. Whether or not the data were measured (or whether the guideline was followed in this respect) did not influence clinical outcome.

Some therapeutic recommendations were followed in $100 \%$ of cases. For instance, all pleurodeses were performed using talc at the recommended dose, no simultaneous bilateral pleurodeses were carried out and the procedure was not performed in combination with biopsy of the visceral pleura. Whether or 


\begin{tabular}{lc} 
TABLE 2 Patient demographics & \\
\hline Subjects & 100 \\
Males & 40 \\
Females & 60 \\
Age yrs & $57(24-82)$ \\
Primary tumour & \\
$\quad$ Mamma & 29 \\
NSCLC & 17 \\
Oesophagus/stomach/colorectal & $9 / 2 / 4$ \\
Renal cell & 6 \\
Ovarian & 6 \\
Carcinoma, unknown primary & 4 \\
Mesothelioma & 3 \\
Sarcoma & 3 \\
Other & 17 \\
Side of pleural effusion & \\
$\quad$ Left & 51 \\
Right & 49 \\
\hline
\end{tabular}

Data are presented as $n$ or median (range). NSCLC: nonsmall cell lung cancer.

not pleurodesis was performed when the pleura approximated the chest wall closely is not clear. The relatively long period between drain positioning and pleurodesis suggests that decision-making during drainage was not solely dependent upon this prognostic factor. In addition, the time of drain removal following pleurodesis, an item on which no recommendation was formulated, differed considerably. The participating centres followed a local strategy ranging from drain removal within $24 \mathrm{~h}$ to drainage for $\geqslant=3$ days following pleurodesis. These different strategies did not result in better outcome, which supports data suggesting that early drain removal is safe and efficient $[15,16]$. Longer drainage extends the period of hospitalisation, which is undesirable for patients with a limited life expectancy.

The present number of successful drain procedures was low in comparison with previously published data. There are several contributory causes for this. First, the present data are presented using intention-to-treat analysis, a method used by only a few of the other authors [17-19]. This implies that patients with a contraindication for pleurodesis after positioning of the drain are included in the denominator of the success rate calculation. This closely reflects daily practice and represented $25 \%$ of the present patients. Omitting this population upgraded the success rate from 32 to $47 \%$. Since these patients do not provide useful information for studies focusing on the effectiveness of pleurodesis agents, they are usually excluded from such studies. This is illustrated in table 4 , which shows the randomised studies on malignant pleural effusion since 2003. The variability in reporting pleurodesis studies, for instance by attrition prior to treatment allocation, has considerable impact upon the reporting of metaanalyses [1]. A more uniform method of describing pleurodesis studies is required.

Secondly, exclusion of patients who died or were lost to follow-up from the analysis improved the success rate of the present series from 47 to $71 \%$, a finding similar to those of

\begin{tabular}{|c|c|c|}
\hline TABLE 3 & \multicolumn{2}{|c|}{$\begin{array}{l}\text { Earlier procedures and characteristics of } \\
\text { pleural fluid }\end{array}$} \\
\hline \multicolumn{3}{|c|}{ Intervention before drainage } \\
\hline \multicolumn{2}{|c|}{ Thoracentesis (diagnostic or therapeutic) } & 66 \\
\hline \multicolumn{2}{|c|}{ Thoracoscopy } & 1 \\
\hline \multicolumn{2}{|c|}{ Pleural drainage and pleurodesis } & 7 \\
\hline \multicolumn{2}{|c|}{ Pleural drainage without pleurodesis } & 1 \\
\hline \multicolumn{2}{|l|}{ None } & 15 \\
\hline \multicolumn{2}{|l|}{ Unknown } & 10 \\
\hline \multicolumn{3}{|c|}{ Pleural fluid composition } \\
\hline \multicolumn{2}{|c|}{ Exudate } & 86 \\
\hline \multicolumn{2}{|l|}{ Transudate } & 5 \\
\hline \multicolumn{2}{|l|}{ Unknown } & 9 \\
\hline \multicolumn{3}{|c|}{ Diagnosis of malignant pleurisy } \\
\hline \multicolumn{2}{|c|}{ Cytologically } & 58 \\
\hline \multicolumn{2}{|c|}{ Histologically } & 5 \\
\hline \multicolumn{2}{|l|}{ Clinically } & 35 \\
\hline \multicolumn{2}{|l|}{ Unknown } & 2 \\
\hline \multicolumn{3}{|l|}{ LDH } \\
\hline \multicolumn{2}{|c|}{ Concentration IU $\cdot \mathrm{L}^{-1}$} & $369(12-4500)$ \\
\hline \multicolumn{2}{|c|}{ Not measured } & 18 \\
\hline \multicolumn{3}{|l|}{ Total protein } \\
\hline \multicolumn{2}{|c|}{ Concentration $\mathrm{g} \cdot \mathrm{L}^{-1}$} & $44(16-65)$ \\
\hline \multicolumn{2}{|c|}{ Not measured } & 25 \\
\hline \multicolumn{3}{|l|}{$\mathrm{pH}$} \\
\hline \multicolumn{2}{|l|}{ Value } & $7.7(7.0-8.5)$ \\
\hline \multicolumn{2}{|c|}{ Not measured } & 54 \\
\hline \multicolumn{3}{|l|}{ Glucose } \\
\hline \multicolumn{2}{|c|}{ Concentration mM } & $5.5(0.1-8.7)$ \\
\hline \multicolumn{2}{|c|}{ Not measured } & 32 \\
\hline
\end{tabular}

Data are presented as $\mathrm{n}$ or median (range). LDH: lactate dehydrogenase.

other studies (table 4) [23]. Thirdly, the present series describes consecutive patients with a symptomatic pleural effusion for whom the physician thought that pleurodesis was the most appropriate therapy. No patients were excluded from the registration.

The present study confirms the importance of complete apposition of the lung to successful pleurodesis, although the data do not permit estimation of the degree of lung apposition that is sufficient for good pleurodesis. The British Thoracic Society guideline recommends pleurodesis even when only partial apposition of the lung can be achieved for symptomatic relief [8], but this cannot be confirmed using the present data. Additionally, it was found that patients who received systemic therapy following pleurodesis exhibited a significantly higher success rate. This might be explained by both less fluid recurrence and better overall survival. This finding supports the recommendation of systemic therapy in several guidelines (table 1) and data from other studies [14, 25]. This recommendation is not supported with a high level of evidence, but the present data also emphasise the benefit of pleurodesis when a new line of systemic treatment is about to be commenced.

The present study was unsuitable for the demonstration of clinical benefit of pleural drainage and pleurodesis. Individual patients might have felt better following treatment despite the 
TABLE 4 Summary of prospective studies on pleurodesis, 2003-2007

\begin{tabular}{|c|c|c|c|c|c|c|}
\hline \multirow[t]{2}{*}{ First author [ref.] } & \multirow[t]{2}{*}{ Year } & \multirow[t]{2}{*}{ Sclerosant } & \multicolumn{3}{|c|}{ Pleurodesis } & \multirow[t]{2}{*}{ Predictors of success } \\
\hline & & & $\begin{array}{c}\text { Inclusion (in)/exclusion (ex) } \\
\text { criteria }\end{array}$ & \multicolumn{2}{|c|}{ Success \% (n) } & \\
\hline GoodmAN [15] & 2006 & $\begin{array}{l}\text { Talc slurry, early versus } \\
\text { late drain removal }\end{array}$ & $\begin{array}{c}\text { In: confirmed MPE; } \\
\text { ex: expected survival } \\
<3 \text { months, KPS } \leqslant 40 \% \text {, } \\
\text { evidence of trapped lung } \\
\text { following drainage, earlier } \\
\text { pleurodesis }\end{array}$ & $\begin{array}{l}87 \text { (16) 24-h group; } \\
78 \text { (19) } 72 \text {-h group }\end{array}$ & $\begin{array}{l}73 \text { (19) 24-h group; } 68 \\
\text { (22) } 72 \text {-h group }\end{array}$ & None given \\
\hline KoLschmanN [22] & 2005 & Talc poudrage & $\begin{array}{l}\text { In: 180-day FU completed, } \\
\text { fit for thoracoscopy; } \\
\text { ex: poor-performance patients }\end{array}$ & $82(46)$ & $37(102)$ & None given \\
\hline Dresler [17] & 2005 & $\begin{array}{l}\text { Talc poudrage } \\
\text { versus slurry }\end{array}$ & $\begin{array}{c}\text { In: life expectancy }>2 \text { months, } \\
\text { ECOG } \leqslant 2 \\
\text { ex: previous pleurodesis }\end{array}$ & $\begin{array}{c}71 \text { (130) slurry; } 78 \\
\text { (152) poudrage: }>90 \% \\
\text { lung expansion and alive }\end{array}$ & $\begin{array}{l}53(240) \text { slurry; } 60 \\
(242) \text { poudrage as } \\
\text { reported in paper }\end{array}$ & None given \\
\hline PASCHOALINI [23] & 2005 & $\begin{array}{l}\text { Talc slurry versus } \\
\text { silver nitrate }\end{array}$ & $\begin{array}{l}\text { In: cytologically proven, KPS } \\
>60 \% \text {, life expectancy } \\
>1 \text { month; ex: trapped lung }\end{array}$ & $\begin{array}{l}100 \text { (16) slurry; } 89 \text { (9) } \\
\text { silver nitrate }\end{array}$ & $\begin{array}{l}40(60) \text { for whole } \\
\text { population }\end{array}$ & None given \\
\hline HADDAD [24] & 2004 & Talc versus bleomycin & $\begin{array}{c}\text { In: recurrent MPE, } \\
\text { thoracentesis with } \\
\text { clinical relief and lung expan- } \\
\text { sion; ex: KPS }<30 \% \text {, earlier } \\
\text { pleurodesis, infection or } \\
\text { chronic air leak }\end{array}$ & $\begin{array}{c}85 \text { (?) talc slurry; } \\
80 \text { (?) bleomycin } \\
\text { (success rate calculated } \\
\text { on } \\
\text { survivors; median survival } \\
2.5 \text { months) }\end{array}$ & $\begin{array}{l}\text { ?\% (37) talc slurry; } \\
\text { ?\% (33) bleomycin }\end{array}$ & $\begin{array}{l}>900 \mathrm{~mL} \text { evacuated } \\
\text { on first thoracentesis }\end{array}$ \\
\hline SARTORI [18] & 2004 & $\begin{array}{l}\text { Bleomycin versus } \\
\text { recombinant IFN- } \alpha\end{array}$ & $\begin{array}{l}\text { In: cytologically proven MPE, } \\
\geqslant 2 \text { thoracenteses and } \\
>3 \mathrm{~L} \text { drained in } 4 \text { weeks, } \\
\text { radiologically proven lung } \\
\text { expansion, } \mathrm{KPS}>40 \%\end{array}$ & & $\begin{array}{l}84 \text { (83) bleomycin; } \\
62 \text { (77) IFN- } \alpha\end{array}$ & None given \\
\hline MASKELL [26] & 2004 & $\begin{array}{l}\text { Graded versus } \\
\text { mixed talc }\end{array}$ & $\begin{array}{l}\text { In: cytologically proven; ex: } \\
\text { expected survival }<6 \text { weeks, } \\
\text { trapped lung after drainage }\end{array}$ & $\begin{array}{l}79(11 / 14) \text { mixed talc } \\
\text { survivors; } 85(12 / 14) \\
\text { graded-talc survivors }\end{array}$ & $41(56)$ & None given \\
\hline CRNJAC [19] & 2004 & $\begin{array}{l}\text { Pleural abrasion versus } \\
\text { talc slurry }\end{array}$ & $\begin{array}{l}\text { In: breast cancer, therapy- } \\
\text { resistant, morphologically } \\
\text { confirmed MPE, fit for surgery }\end{array}$ & & $\begin{array}{l}13(45) \text { mechanical } \\
\text { pleurodesis; } 26(42) \\
\text { talc slurry }\end{array}$ & $\mathrm{pH}>7.3$ \\
\hline KuZDZAL [27] & 2003 & $\begin{array}{c}\text { Talc powder versus } \\
\text { doxycycline }\end{array}$ & $\begin{array}{l}\text { Ex: mesothelioma, no full } \\
\text { re-expansion of the lung, no } \\
\text { histological confirmation of } \\
\text { malignant pleurisy }\end{array}$ & $\begin{array}{l}100 \text { (18) talc; } 40 \text { (15) } \\
\text { doxycycline }\end{array}$ & $\begin{array}{l}44(54) \text { whole } \\
\text { population }\end{array}$ & None given \\
\hline
\end{tabular}

Studies were identified by PubMed search using the terms "pleurodesis" and "pleural effusion, malignant". The search was limited to full papers in the English language IFN: interferon; MPE: malignant pleural effusion; KPS: Karnofsky Performance Status; FU: follow-up; ECOG: Eastern Cooperative Oncology Group [status]; ?: data not given in study. 
procedure being listed as a failure according to the standards of the present study. Only a few days with diminished dyspnoea might be much appreciated. The question remains as to whether or not other less invasive treatments, such as repeated thoracentesis, which require less time in hospital, could have been equally effective (table 1).

Only few QoL data following pleurodesis are available, which stresses the difficulties that arise when QoL is measured in a population with a poor prognosis. One study assuming that QoL paralleled the performance status of patients stated that this was a good predictor of successful pleurodesis [28]. Comparison of QoL following thoracoscopic talc poudrage and pleurodesis by talc slurry revealed that patients perceived greater comfort and medical safety and less fatigue when treated thoroscopically [17].

In conclusion, despite the availability of national guidelines and reasonable adherence to the recommendations therein, the outcome of pleurodesis in the present unselected population was poor. Obviously, in daily clinical practice, it was not possible to discriminate patients who were likely to benefit from hospitalisation and pleurodesis from those who were not. Thus robust predictors that are available before the drain is placed are needed. One example might be the availability of a systemic antineoplastic treatment. Prospective validation of these known and other new predictors of treatment success is warranted.

\section{ACKNOWLEDGEMENTS}

The authors are grateful to N. Antonini for statistical assistance and D. Baars for creating the e-database (both from the Netherlands Cancer Institute, Amsterdam, the Netherlands).

\section{REFERENCES}

1 Shaw P, Agarwal R. Pleurodesis for malignant pleural effusions. Cochrane Database Syst Rev 2004; Issue, 1: CD002916.

2 Groen H, Welling A, Postmus PE, van Meerbeeck JP, van Kasteren JHLM. Diagnostiek en behandeling van maligne pleuravocht. Richtlijn van de Nederlandse Vereniging van Artsen voor Longziekten en Tuberculose. [Diagnosis and Treatment of Malignant Pleural Effusions. Guideline of the Dutch Society of Pulmonologists.] Alphen aan den Rijn, van Zuiden Communications, 2003.

3 Dutch Institute for Healthcare Improvement CBO. Development of evidence-based clinical practice guidelines. www.cbo.nl/product/richtlijnen/handleiding_ebro/ brochure_ebro_eng.pdf? Date last updated: 2006. Date last accessed: 25 August 2008.

4 Harbour R, Miller J. A new system for grading recommendations in evidence based guidelines. BMJ 2001; 323: 334-336.

5 Davies RJ, Gleeson FV. Introduction to the methods used in the generation of the British Thoracic Society guidelines for the management of pleural diseases. Thorax 2003; 58: Suppl. 2, ii1-ii7.

6 Teixeira LR, de Figueiredo Pinto JA, Marchi E. Derrame pleural neoplasico. [Malignant pleural effusion.]. J Bras Pneumol 2006; 32: S182-S189.
7 Antony VB, Loddenkemper R, Astoul P, et al. Management of malignant pleural effusions. Eur Respir J 2001; 18: 402-419.

8 Antunes G, Neville E, Duffy J, Ali N. BTS guidelines for the management of malignant pleural effusions. Thorax 2003; 58: Suppl. 2, ii29-ii38.

9 Maskell NA, Butland RJ. BTS guidelines for the investigation of a unilateral pleural effusion in adults. Thorax 2003; 58: Suppl. 2, ii8-ii17.

10 Garrido VV, Sancho J, Blasco H, et al. Diagnosis and treatment of pleural effusion. Recommendations of the Spanish Society of Pulmonology and Thoracic Surgery (SEPAR). Arch Bronconeumol 2006; 42: 349-372.

11 Grol R, Grimshaw J. From best evidence to best practice: effective implementation of change in patients' care. Lancet 2003; 362: 1225-1230.

12 Grimshaw JM, Shirran L, Thomas R, et al. Changing provider behavior: an overview of systematic reviews of interventions. Med Care 2001; 39: Suppl. 2, II2-II45.

13 Heffner JE, Nietert PJ, Barbieri C. Pleural fluid $\mathrm{pH}$ as a predictor of survival for patients with malignant pleural effusions. Chest 2000; 117: 79-86.

14 Martinez-Moragon E, Aparicio J, Sanchis J, Menendez R, Cruz Rogado M, Sanchis F. Malignant pleural effusion: prognostic factors for survival and response to chemical pleurodesis in a series of 120 cases. Respiration 1998; 65: 108-113.

15 Goodman A, Davies CW. Efficacy of short-term versus long-term chest tube drainage following talc slurry pleurodesis in patients with malignant pleural effusions: a randomised trial. Lung Cancer 2006; 54: 51-55.

16 Yildirim E, Dural K, Yazkan R, et al. Rapid pleurodesis in symptomatic malignant pleural effusion. Eur J Cardiothorac Surg 2005; 27: 19-22.

17 Dresler CM, Olak J, Herndon JE 2nd, et al. Phase III intergroup study of talc poudrage versus talc slurry sclerosis for malignant pleural effusion. Chest 2005; 127: 909-915.

18 Sartori S, Tassinari D, Ceccotti P, et al. Prospective randomized trial of intrapleural bleomycin versus interferon alfa- $2 b$ via ultrasound-guided small-bore chest tube in the palliative treatment of malignant pleural effusions. $J$ Clin Oncol 2004; 22: 1228-1233.

19 Crnjac A, Sok M, Kamenik M. Impact of pleural effusion $\mathrm{pH}$ on the efficacy of thoracoscopic mechanical pleurodesis in patients with breast carcinoma. Eur J Cardiothorac Surg 2004; 26: 432-436.

20 Psathakis K, Calderon-Osuna E, Romero-Romero B, MartinJuan J, Romero-Falcon A, Rodriguez-Panadero F. The neutrophilic and fibrinolytic response to talc can predict the outcome of pleurodesis. Eur Respir J 2006; 27: 817-821.

21 Stefani A, Natali P, Casali C, Morandi U. Talc poudrage versus talc slurry in the treatment of malignant pleural effusion. A prospective comparative study. Eur J Cardiothorac Surg 2006; 30: 827-832.

22 Kolschmann S, Ballin A, Gillissen A. Clinical efficacy and safety of thoracoscopic talc pleurodesis in malignant pleural effusions. Chest 2005; 128: 1431-1435.

23 da Silveira Paschoalini M, Vargas FS, Marchi E, et al. Prospective randomized trial of silver nitrate $v$ s talc slurry in pleurodesis for symptomatic malignant pleural effusions. Chest 2005; 128: 684-689. 
24 Haddad FJ, Younes RN, Gross JL, Deheinzelin D. Pleurodesis in patients with malignant pleural effusions: talc slurry or bleomycin? Results of a prospective randomized trial. World J Surg 2004; 28: 749-753, discussion 753-754.

25 Ukale V, Agrenius V, Hillerdal G, Mohlkert D, Widstrom O. Pleurodesis in recurrent pleural effusions: a randomized comparison of a classical and a currently popular drug. Lung Cancer 2004; 43: 323-328.

26 Maskell NA, Lee YC, Gleeson FV, Hedley EL, Pengelly G, Davies RJ. Randomized trials describing lung inflammation after pleurodesis with talc of varying particle size. Am J Respir Crit Care Med 2004; 170: 377-382.

27 Kuzdzal J, Sladek K, Wasowski D, et al. Talc powder vs doxycycline in the control of malignant pleural effusion: a prospective, randomized trial. Med Sci Monit 2003; 9: PI54-PI59.

28 Burrows CM, Mathews WC, Colt HG. Predicting survival in patients with recurrent symptomatic malignant pleural effusions: an assessment of the prognostic values of physiologic, morphologic, and quality of life measures of extent of disease. Chest 2000; 117: 73-78. 